\title{
Mechanisms of endocrine therapy-responsive and -unresponsive prostate tumours
}

\author{
Z Culig, H Steiner, G Bartsch and A Hobisch ${ }^{1}$
}

Department of Urology, Innsbruck Medical University, Anichstrasse 35, A-6020 Innsbruck, Austria

${ }^{1}$ Department of Urology, General Hospital Feldkirch, Cariuagasse 45, A-6800 Feldkirch, Austria

(Requests for offprints should be addressed to Z Culig; Email: zoran.culig@uibk.ac.at)

\begin{abstract}
Several options for the endocrine treatment of non-organ-confined prostate cancer are available. They include surgical or medical removal of androgenic hormones or administration of non-steroidal anti-androgens. However, tumour progression after a period of remission of the disease inevitably occurs in virtually all patients. The androgen receptor (AR) is, in various tumour models, implicated in the development of therapy resistance but molecular mechanisms that by-pass the receptor have also been described. Adaptation mechanisms relevant to tumour recurrence include up-regulation of AR mRNA and protein, overexpression of AR coactivators, increased activation of mutated receptors by steroids and anti-androgens, and ligand-independent activation. For research studies, sublines that respond to but do not depend on androgen for their proliferation were generated. Coactivators SRC-1, TIF-2, RAC3, p300, CBP, Tip60, and gelsolin are highly expressed in endocrine therapy-resistant prostate cancer. AR point mutations are increasingly detected in relapsed cancers and contribute to the failure of endocrine therapy in a subgroup of patients. Ligand-independent activation of the AR by HER-2/neu and interleukin- 6 is associated with activation of the signalling pathway of mitogen-activated protein kinase. Increased activity of intracellular kinases may affect cellular events in both an AR-dependent and -independent manner. Mitogen-activated protein kinases are strongly phosphorylated in endocrine therapy-resistant prostate tumours. Similarly, activation of the AR by phosphorylated protein kinase B, Akt, has also been reported in prostate cancer. Activation of the Akt pathway contributes to increased survival of prostate tumour cells.
\end{abstract}

Endocrine-Related Cancer (2005) 12 229-244

\section{Introduction}

Responsiveness of normal and malignant prostate to androgenic stimulation is determined by the presence of the androgen receptor (AR) in epithelial and adjacent stromal prostate cells. Malignant prostate tumours respond to androgen ablation by retardation of growth (Huggins \& Hodges 1941). This recognition has greatly influenced therapeutical concepts in human prostate cancer over decades. Androgen ablation therapy was introduced for treatment of non-organ-confined prostate cancer and its effectiveness in stabilization of the disease has not been surpassed by any other treatment. Removal of androgen may be achieved either by castration or administration of luteinizing hormone-releasing hormone (LHRH) analogues. These drugs lead to desensitization of luteinizing hormone receptors and subsequent inhibition of testosterone production. Besides androgen ablation, endocrine approaches aimed to control prostate cancer growth include blockade of the AR, a transcription factor responsible for regulation of genes involved in control of proliferation, apoptosis, angiogenesis, and differentiation in prostate. At present, the nonsteroidal AR antagonists hydroxyflutamide and bicalutamide are widely used in prostate cancer endocrine therapy. The AR structure is similar to that of other steroid receptors; it consists of well-conserved DNAand ligand-binding domains and the $\mathrm{N}$-terminal region that contains a variable number of polyglutamine and 
polyglycine repeats. A more detailed review of basic aspects of AR action has been published elsewhere (Gobinet et al. 2002). AR antagonists prevent acquisition of a transcriptionally active conformation of the AR and are commonly administered as a monotherapy or during initial phases of treatment with LHRH analogues. However, there is a need to obtain more results from large clinical trials to compare the effectiveness of non-steroidal anti-androgens with that of androgen ablation. With regard to the quality of life of the patients, anti-androgen monotherapy offers advances over androgen withdrawal.

In the last decade, the number of available models relevant to human carcinoma of the prostate has increased and the complexity of pathways implicated in tumour progression have become obvious. The responsiveness of prostate cancers to steroid hormones varies at different stages of prostate carcinogenesis. Novel findings as to how steroid and peptide hormones control prostate growth have opened new possibilities for the development of therapeutic agents to target selected molecules. However, it has also become clear that the heterogeneity of prostate cancers requires an individualized approach in order to achieve a prolonged stable phase of the disease.

The purpose of this review is to delineate the most common mechanisms underlying the progression of prostate cancer towards therapy resistance. It will therefore focus on the role of androgenic signalling as well as on kinase pathways that by-pass steroid receptors.

\section{Heterogenous expression of AR in prostate cancer cells and clinical specimens}

The presence of the AR was clearly demonstrated in prostate tissues obtained from patients who failed therapy, lymph node, and distant metastases (Van der Kwast et al. 1991, Hobisch et al. 1995, 1996). High AR expression in epithelium and concomitant reduced expression in stroma are associated with high tumour grade (Henshall et al. 2001). However, the mechanistic link between growth advantage and loss of stromal AR in prostate cancer requires further investigations.

AR expression in prostate cancers is influenced by post-translational and epigenetic modifications. In vitro, $\mathrm{AR}$ expression has frequently been studied in $\mathrm{LNCaP}$ cells derived from a lymph node metastasis from a patient who failed endocrine therapy (Horoszewicz et al. 1983). From those studies, it became clear that there are differences in androgenic regulation of AR mRNA and protein (Fig. 1) (Krongrad et al. 1991).
The inhibitory effect on mRNA is compensated by the stabilization of the AR protein by androgen. AR expression in LNCaP cells is inhibited by epidermal growth factor (EGF) and transforming growth factor (EGF)- $\alpha$ at the mRNA level (Henttu \& Vihko 1993). It is important to note however that growth factors might exhibit opposite effects on the expression and activity of the AR. Inhibition of AR protein expression in prostate cancer cells was observed in conditions in which proliferation is down-regulated by chemopreventive compounds, such as vitamin E, resveratrol, the non-steroidal anti-inflammatory drugs flufenamic acid and exisulind, and selenium (Mitchell et al. 1999, Zhu et al. 1999, Zhang et al. 2002, Lim et al. 2003, Dong et al. 2004) (Fig. 1). This treatment results in a diminished expression of androgen-target genes, such as the prostate-specific antigen (PSA) gene. Thus, the treatment outcome is similar to that reported after administration of $\mathrm{AR}$ antisense oligonucleotides or neutralizing antibodies to LNCaP cells (Eder et al. 2000, Zegarra-Moro et al. 2002). The AR is implicated in the development of endocrine therapy resistance by various non-exclusive mechanisms. Several studies on the role of the AR in prostate cancer progression were carried out with steroid-deprived cells generated to mimic the clinical situation. During long-term androgen ablation, the levels of AR mRNA and protein become up-regulated in LNCaP and MDA PCa2b cells (Kokontis et al. 1994, Culig et al. 1999, Hara et al. 2003a). AR levels increase in recurrent prostate cancer, in some cases as a result of protein stabilization (Gregory et al. 2001a). This change facilitates the development of receptor hypersensitivity and aberrant reaction to anti-androgens. Because of a decreased threshold for receptor stimulation in patients who are subjected to androgen withdrawal, the presence of adrenal precursors of testicular androgens may be relevant to the regulation of prostate cancer growth and apoptosis. In concordance with data obtained with $\mathrm{LNCaP}$ cells in vitro, genetic profiling of a series of prostate cancer xenografts revealed that the most consistent change during transition to the endocrine therapy-insensitive stage is AR up-regulation, associated with agonism of AR blockers and changes in the relative abundance of coactivators or corepressors assembled on the promoters of AR target genes (Chen et al. 2004). In a subline of $\mathrm{LNCaP}$ cells derived during continuous androgen withdrawal in vitro, stimulation of reporter gene activity by bicalutamide was also evident (Culig et al. 1999). Although it did not reach the same levels as transcriptional activity measured after incubation with androgen, it was sufficient for induction of the stimulation of growth of the androgen-ablated 


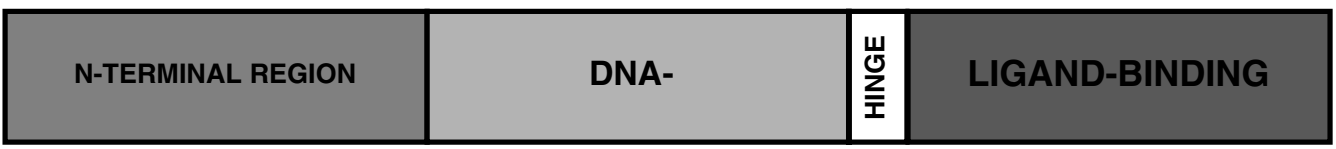

mRNA -

(Krongrad et al. 1991)

\section{Protein}

\section{ANDROGEN (Lee et al. 1995) \\ LONG-TERM ANDROGEN ABLATION \\ (Kokontis et al. 1994 Culig et al. 1999) \\ VITAMIN D (Zhao et al. 1999b)}

\section{+ Activity}

IL-6 (Hobisch et al. 1998)

Her-2 (Craft et al. 1999)

PKA (Nazareth \& Weigel, 1996)

EGF (Culig et al. 1994, Reinikainen et al. 1996)

\author{
EGF, TGF- $\beta$, HEPARIN-BINDING EGF (Henttu and Vihko 1993, \\ Adam 2002) \\ SELENIUM (Dong et al. 2004) \\ RESVERATROL, QUERCETIN (Mitchell et al. 1999, Xing el al. 2001) \\ NON-STEROIDAL ANTINFLAMMATORY DRUGS (Lim et al. 2003) \\ IL-1 (Culig et al. 1998) \\ bFGF (Cronauer et al. 2000)
}

Figure 1 Compounds that up- or down-regulate the AR expression in human prostate cancer. The AR consists of a wellconserved DNA- and ligand-binding domain that are separated by a hinge region, and the N-terminal region. Several cytokines implicated in the regulation of prostate cancer growth modulate AR levels.

subline in vitro and in vivo. In a recently published study in which tissues from patients with relapsed cancer were obtained, AR mean optical density was similar to that in benign prostate (Mohler et al. 2004). Those data indicated that the AR in therapy-resistant tumours is present at levels that allow stimulation by androgens, such as androstanediol, which is persistent at high concentrations in prostate tissue after castration (Mizokami et al. 2004). Evidence for reactivation of the androgen signalling cascade was also obtained in a gene profiling study in human prostate cancer (Holzbeierlein et al. 2004). Data on increased AR protein expression are complemented by those obtained in studies investigating AR gene copy number in recurrent prostate tumours. AR gene amplification occurs in a subgroup of patients who present with tumour progression after endocrine treatment (Visakorpi et al. 1995, Linja et al. 2001). However, there is no conclusive evidence that AR amplification is causally associated with failure of endocrine therapy. There is no difference in time to relapse between patients who present with AR amplification compared with those without change in AR gene copy number (Edwards et al. 2003). Interestingly, on the basis of data from a group of 77 patients, Palmberg et al.
(2000) proposed that AR amplification is linked to a favourable response to complete androgen blockade. One possibility to explain these findings is an involvement of the AR in the regulation of prostate differentiation. Endocrine therapy could be more efficient in well-differentiated tumour tissue.

AR expression in clinical samples is heterogenous and its lower levels in some cells could be explained by hypermethylation of the promoter island $\mathrm{CpG}$ in the AR gene (Jarrard et al. 1998). This phenomenon was initially observed in the DU-145 cell line, in which treatment with the demethylating agent 5-aza-2' deoxycytidine led to the re-expression of the AR and PSA. The AR gene is hypermethylated in about $30 \%$ of cases of recurrent prostate cancer (Nakayama et al. 2000). The findings obtained with DU-145 cells therefore have clinical significance.

\section{The relevance of prostate cancer sublines derived in androgen-depleted conditions for understanding the mechanisms of tumour progression}

Sublines generated from prostate cancer cells that respond to androgen but do not require it for their 
Table 1 Overview of cell lines and their derivatives commonly used in research on androgenic responsiveness

\begin{tabular}{|c|c|}
\hline Cells & Characteristic features \\
\hline LNCaP & $\begin{array}{l}\text { Mutated AR Thr868Ala, promiscuous } \\
\text { activation, hydroxyflutamide agonist } \\
\text { (Veldscholte et al. 1990) }\end{array}$ \\
\hline $\begin{array}{l}\text { Androgen-deprived } \\
\text { LNCaP }\end{array}$ & $\begin{array}{l}\text { Hypersensitive AR, some sublines } \\
\text { stimulated by bicalutamide } \\
\text { PSA expression diminished, AR mutation } \\
\text { Thr868Ala (Kokontis et al. 1994, } \\
\text { Culig et al. 1999) }\end{array}$ \\
\hline LNCaP C4-2 & $\begin{array}{l}\text { High basal PSA levels } \\
\text { Androgen-independent recruitment } \\
\text { of the Tip60 coactivator AR mutation } \\
\text { Thr868Ala (Wu et al. 1994) }\end{array}$ \\
\hline CWR22-Rv1 & $\begin{array}{l}\text { Mutated AR His874Tyr and in-frame } \\
\text { duplication of exon } 3 \text { androgen- } \\
\text { independent expression of } \\
\text { AR downstream genes (McDonald } \\
\text { et al. } 2000 \text {, Tepper et al. 2002) }\end{array}$ \\
\hline LAPC 4 & $\begin{array}{l}\text { Ligand-independent induction of AR } \\
\text { by HER-2 (Craft et al. 1999) }\end{array}$ \\
\hline MDA PCa $2 a$ & $\begin{array}{l}\text { Double AR mutant Leu701His and } \\
\text { Thr877Ala (Zhao et al. 1999a) }\end{array}$ \\
\hline $\mathrm{AR} \mathrm{CaP}$ & $\begin{array}{l}\text { Androgenic inhibition of tumour cell } \\
\text { growth (Cinar et al. 2001) }\end{array}$ \\
\hline PC-3 AR & $\begin{array}{l}\text { Androgenic induction of growth arrest } \\
\text { and apoptosis, wild-type } \\
\text { AR (Heisler et al. 1997) }\end{array}$ \\
\hline
\end{tabular}

growth are suitable models for studies on changes in androgen signalling (Table 1). In general, LNCaP cells are sensitive to acute androgen ablation to which they respond by growth retardation. However, various adaptation mechanisms are operative during chronic maintenance in a steroid-depleted environment. One of the most frequently used LNCaP sublines is C4-2 cells, derived during in vivo propagation in castrated animals (Wu et al. 1994). They acquire a higher invasive and metastatic potential and up-regulate PSA baseline levels (Thalmann et al. 1994). This PSA up-regulation is in contrast to that observed in cells selected by longterm androgen ablation or interleukin (IL)-6 treatment in vitro, in which PSA expression is considerably reduced (Gao et al. 1999, Hobisch et al. 2001). PSA gene silencing in a subline derived during continuous androgen withdrawal in vitro is due to hypermethylation (Wang et al. 2001). Thus, in some prostate cancer patients, the expression of PSA might be low or undetectable despite AR expression. It is therefore not surprising that there is a considerable heterogenity in expression of these proteins when metastatic lesions from various sites from the same patient are compared
(Shah et al. 2004). In fact, there is no strong correlation between their expression in metastatic lesions. Downregulation of $\mathrm{AR}$ protein by antisense oligonucleotides in an androgen-deprived subline was associated with an increase in the levels of the cell cycle inhibitor p21WAF1 and reacquisition of the androgendependent phenotype (Wang et al. 2001). In the CWR22 xenograft model system, sublines with variable growth phenotypes emerged 80 to 400 days after androgen withdrawal (Agus et al. 1999). In the relapsed prostate cancer xenograft CWR22, there is an increased expression of multiple AR-regulated genes (Gregory et al. 1998, Kim et al. 2002). The data from Gregory et al. (1998) and Kim et al. (2002) demonstrated that the AR signalling pathway is functional in hormone therapy-refractory prostate cancer. In fact, this conclusion has been reached with different methodological approaches in various models. The cell line CWR22-Rv1 was used for studies on hormonal responsiveness in advanced prostate cancer (Attardi et al. 2004). These authors showed that the cells become stimulated by a wide range of steroid hormones. This aberrant stimulation might occur as a result of an in-frame tandem duplication of exon 3 that encodes the second zinc finger of the DNA-binding domain of the AR (Tepper et al. 2002). In contrast to models representative of chronic androgen ablation, the regulation of AR expression does not correlate with proliferative changes during intermittent androgen ablation. We have recently established a series of LNCaP sublines after intermittent androgen withdrawal in vitro (Hobisch et al. 2004). In that model system, AR protein expression is up-regulated during prolonged androgen deprivation and inhibited after subsequent addition of androgen. However, these cells acquired a growth advantage and the proliferation was not inhibited in sublines that down-regulate the AR. Thus, the AR signalling pathway might be by-passed during the progression of prostate cancers treated with intermittent androgen ablation. It could be speculated that an increased expression of several cytokines contributes to activation of intracellular kinase pathways and growth advantage in sublines that mimic intermittent androgen withdrawal.

Sublines derived under androgen-depleted conditions are reliable models with which to study interaction with AR cofactors under pathological conditions. AR coactivators, proteins with histone acetyltransferase activity, interact with one or more domains of the AR, thus leading to remodelling of the chromatin structure through the acetylation of histones. Not only expression, but also functional interactions of coregulatory proteins, may be altered in the late stages of prostate 
cancer. The coactivator Tip60 could be recruited in the absence of androgen to the promoter of the PSA gene in an androgen-deprived LNCaP subline but not in the parental cells (Halkidou et al. 2003). This mechanism might be operative with other coactivators in prostate cancer thus enhancing expression of AR target genes in late tumour stages.

It should however be mentioned that PC-3 cells stably transfected with AR cDNA have been used in prostate cancer biology studies. In that cellular context, AR re-expression was clearly associated with a less malignant phenotype. Androgen treatment of AR-expressing PC-3 cells blocks progression through the cell cycle leading to growth inhibition and apoptosis (Heisler et al. 1997). Similar observations were made with the ARCaP cell line which is derived from ascites from a prostate cancer patient and which expresses endogenous AR (Cinar et al. 2001). Although the relevance of these models needs to be studied further, the results raise some questions about the limitations of therapeutic intervention focused on the AR.

\section{AR coactivator alterations occur in endocrine therapy-resistant prostate cancer}

Although a large number of AR-interacting proteins have been detected in androgen-target tissues, the relevance of most of them for the development of prostate cancer and progression towards therapy resistance remains to be determined. Recently, increasing numbers of cofactor antibodies have become available and the expression of a subgroup of them has been demonstrated at different stages of prostate carcinogenesis (Table 2). It was demonstrated that increased expression of SRC-1 and TIF-2 coactivator proteins contributes to prostate cancer progression (Gregory et al. 2001b). As a consequence of overexpression of these cofactors, there is a reduced threshold for androgenic steroids needed to activate the AR. However, regulation of SRC-1 mRNA and protein levels in prostate cancer is not completely understood. In a group of patients with therapyresistant prostate cancer, there was a lower expression of SRC-1 mRNA compared with that in untreated patients (Linja et al. 2004). Amplification and overexpression of SRC-1 mRNA were seen only in the LuCaP 70 xenograft but not in specimens obtained from patients who failed endocrine therapy. It is, however, difficult to compare both studies without caution since Linja et al. (2004) investigated mRNA
Table 2 Selected AR coactivators and their functional importance in prostate cancer

\begin{tabular}{|c|c|}
\hline Coactivator & Expression and function in prostate cancer \\
\hline SRC-1 & $\begin{array}{l}\text { Up-regulation in therapy-refractory } \\
\text { tumours (Gregory et al. } 2001 b \text { ) } \\
\text { Implicated in ligand-independent activation } \\
\text { by IL-6 (Ueda et al. 2002b) }\end{array}$ \\
\hline TIF-2 & $\begin{array}{l}\text { Up-regulation in therapy-refractory prostate } \\
\text { cancer (Gregory et al. } 2001 \mathrm{~b} \text { ) } \\
\text { Involvement in synergistic activation by } \\
\text { androgen and EGF (Gregory et al. 2004) }\end{array}$ \\
\hline CBP & $\begin{array}{l}\text { Potentiation of agonistic effects of } \\
\text { hydroxyflutamide (Comuzzi et al. 2003) } \\
\text { Up-regulation by androgen ablation } \\
\text { (Comuzzi et al. 2004) }\end{array}$ \\
\hline p300 & $\begin{array}{l}\text { Required for ligand-independent activation } \\
\text { by IL-6 (Debes et al. 2002) }\end{array}$ \\
\hline RAC3 & $\begin{array}{l}\text { Correlation with prostate cancer grade and } \\
\text { stage (Gnanapragasam et al. 2001) }\end{array}$ \\
\hline ARA70 & $\begin{array}{l}\text { Enhancement of AR activation by several } \\
\text { steroids and non-steroidal AR antagonists } \\
\text { (Yeh et al. 1998, Miyamoto et al. 1998) }\end{array}$ \\
\hline ARA55 & $\begin{array}{l}\text { AR coactivation in the presence of either } \\
\text { androgen, oestradiol, or hydroxyflutamide } \\
\text { (Fujimoto et al. 1999) }\end{array}$ \\
\hline ARA54 & $\begin{array}{l}\text { Enhancement of transcriptional activity of the } \\
\text { LNCaP AR in the presence of oestradiol or } \\
\text { hydroxyflutamide (Kang et al. 1999) }\end{array}$ \\
\hline ART 27 & $\begin{array}{l}\text { Very low expression in prostate cancer } \\
\text { (Taneja et al. 2004) }\end{array}$ \\
\hline Cdc25B & $\begin{array}{l}\text { Overexpressed in prostate cancer } \\
\text { (Ngan et al. 2002) }\end{array}$ \\
\hline Tip60 & $\begin{array}{l}\text { Nuclear accumulation in advanced } \\
\text { prostate cancer } \\
\text { Up-regulation by androgen ablation } \\
\text { (Halkidou et al. 2003) }\end{array}$ \\
\hline Gelsolin & $\begin{array}{l}\text { Potentiation of agonistic effects of } \\
\text { hydroxyflutamide up-regulated by androgen } \\
\text { ablation (Nishimura et al. 2003) }\end{array}$ \\
\hline
\end{tabular}

expression. SRC-1 is involved in ligand-independent activation of the AR by IL-6, a cytokine that regulates proliferation, apoptosis, and angiogenesis in prostate cancer (Ueda et al. 2002). The AR-associated protein RAC3, a member of the p160 family of coactivators, is expressed in $\mathrm{LNCaP}$ cells at a higher level than in PC-3 or DU-145 cells respectively (Gnanapragasam et al. 2001). Most AR cofactors also have a regulatory function in AR-negative prostate cancer cell lines. In clinical samples, RAC3 expression correlates with prostate tumour grade and stage and poorer diseasespecific survival. An inhibitory effect of androgen on the expression of AR cofactors was described in the case of 
Tip60, cAMP Response Element-Binding ProteinBinding Protein (CBP), or gelsolin (Halkidou et al. 2003, Nishimura et al. 2003, Comuzzi et al. 2004). A marked potentiation of AR activity by hydroxyflutamide was observed in the presence of CBP or gelsolin (Comuzzi et al. 2003, Nishimura et al. 2003). High expression levels of these coactivators were found in samples obtained from patients who failed endocrine therapy. These findings suggest that one of the reasons for failure of prostate cancer hormonal therapy is up-regulation of AR coactivator proteins which may be linked to a hypersensitive androgen signalling pathway. The coactivators may thus contribute to the anti-androgen withdrawal syndrome, which is characterized by a time-limited improvement in the condition of the patients after withdrawal of an anti-androgen. In patients who underwent radical prostatectomy, the levels of expression of the functional homologue of CBP, p300, correlated with proliferation, tumour volumes, extraprostatic extension, and seminal vesicle involvement (Debes et al. 2002). The main constituent of caveolae membranes, caveolin, associates with the AR thus leading to enhancement of its transcriptional activity in a ligand-dependent manner ( $\mathrm{Lu}$ et al. 2001). Targeting interactions between these coactivators and the AR may thus improve the effectiveness of endocrine therapy.

It has been proposed that alterations in the expression or function of several cofactors that are more specific for the AR occur in prostate tumours. In this context, the cofactor ARA70, which potentiates $\mathrm{AR}$ activation in the presence of testicular and adrenal androgens, oestradiol, and anti-androgens (Heinlein \& Chang 2004), has been studied extensively. Li et al. (2002) found a decreased expression of ARA70 in prostate cancer tissues by in situ hybridization. Consistent with these results, proliferation of $\mathrm{LNCaP}$ cells and colony formation were inhibited after overexpression of ARA70, thus suggesting its role as a tumour suppressor. There is also evidence that expression levels of the coactivator AR trapped clone-27 (ART-27) are substantially decreased in prostate cancer tissues (Taneja et al. 2004).

In contrast, data from $\mathrm{Hu}$ et al. (2004) showed an increase in ARA70 protein in high-grade prostate cancers and cells cultured in androgen-deficient conditions. More research is needed to clarify the reasons for these contrasting results. The use of a dominantnegative mutant of ARA70 led to inhibition of LNCaP proliferation; however, the contribution of inhibition of an individual AR coactivator to a potential antitumour effect should be further investigated in vivo (Rahman et al. 2003). Due to interactions between the
AR and its various partner proteins, several other cofactors could compensate for the loss of one of them. AR transcription activation function is potentiated by cyclin $\mathrm{E}$ through interaction with the receptor $\mathrm{N}$-terminal region (Yamamoto et al. 2000). This interaction is likely to be relevant to the mitogenic effect of androgenic hormones in prostate cancer. Overexpression of cdc25B, a dual-specific phosphatase which activates cyclin-dependent kinases and enhances AR activation, was reported in prostate cancer patients (Ngan et al. 2002). Conversely, the tumour suppressor retinoblastoma also potentiates AR activation (Yeh et al. 1998). Similarly, coactivation of the AR by the breast cancer susceptibility gene BRCA1 is associated with induction of apoptosis (Yeh et al. 2000).

Alterations in AR corepressors may also be associated with therapy failure in prostate cancer. The corepressor Silencing Mediator of Retinoid and Thyroid Hormone Receptors (SMRT) decreased induction of AR activity by androgen through inhibition of $\mathrm{N} / \mathrm{C}$ interactions (Liao et al. 2003a). AR activation is also inhibited by cyclin D1 (Petre-Draviam et al. 2003). At present, there are no data available on corepressor expression alterations in clinical prostate cancer material.

\section{Impact of mutated AR for prostate cancer progression towards resistance to hormonal therapy}

AR point mutations were intensively studied in prostate cancer cell lines and clinical specimens. Although some controversies regarding their frequency in prostate tumors still exist in the literature, there is a consensus that they contribute to failure of endocrine therapy in a subgroup of patients (Taplin et al. 2003). Interestingly, no correlation between AR mutations and survival or the anti-androgen withdrawal syndrome was found. Detection of mutations in prostate cancer tissue was improved when material obtained by laser capture microdissection was used (Marcelli et al. 2000). Mutations are more common in patients with high-grade cancer as well as in those with distant metastases. In these tumour stages, several other genetic alterations occur and this could be a reason why the correlation with patient survival has not been established. Mutations in the $\mathrm{N}$-terminal region of the AR were detected in patients treated with orchiectomy and estramustine, whereas in individuals treated with orchiectomy alone somatic AR mutations were located predominantly in the ligand-binding domain (Hyytinen et al. 2002). A mutation in the hinge region of the AR detected in a patient with high-grade prostate cancer (Ser646Phe) leads to an increased functional activity of 
the AR (Thompson et al. 2003). Several AR mutations were characterized in the mouse transgenic adenocarcinoma of the prostate model (Buchanan et al. 2001). Mutations at the boundary of the hinge and ligand-binding domain yield increased transactivation. AR mutations that broaden the activation spectrum are present in human cell lines LNCaP, MDA PCa 2a, and the xenograft CWR22. The mutated LNCaP AR was characterized in a number of research studies that yielded consensus regarding its activation by oestrogenic and progestagenic steroids, adrenal androgens, glucocorticoids, and the anti-androgen hydroxyflutamide (Veldscholte et al. 1990, Chang et al. 2001). Bicalutamide is the only anti-androgen which retains antagonistic properties in LNCaP cells (Veldscholte et al. 1992). The AR mutant in MDA PCa 2a cells contains the two alterations, Leu701His and Thr877Ala (Zhao et al. 1999a). That receptor binds cortisol with a high affinity (Zhao et al. 2000). Activation of the MDA PCa 2a AR by cortisol is associated with induction of PSA expression and stimulation of growth. The CWR22 AR contains a mutation at codon 874 (His replaced by Tyr) and shows an increased activation by adrenal androgens and hydroxyflutamide (Tan et al. 1997). Adrenal androgens are also potent activators of the mutated AR Val715Met and Val730Met (Culig et al. 1993, Peterziel et al. 1995). The question whether the treatment with antiandrogens itself has an influence on frequency of point mutations was addressed in vitro and in vivo. Hara et al. $(2003 b)$ described mutations in a subline of LNCaP cells which were chronically treated with bicalutamide. The AR mutations detected led to an exchange of Trp at position 741 to Cys or Leu. Most interestingly, these were the same mutations as those previously discovered in tissues of prostate cancer patients who received bicalutamide therapy (Haapala et al. 2001). Mutations at AR codon 741 result in acquisition of agonistic properties of bicalutamide and hydroxyflutamide antagonism, in contrast to parental LNCaP cells. Conversely, a possible role for bicalutamide as a 'second-line' treatment was proposed for mutated receptors that increasingly respond to hydroxyflutamide (Joyce et al. 1998, Taplin et al. 1999).

The most rapid approach in the analysis of functional properties of mutated $\mathrm{AR}$ is the use of a colorimetric yeast reporter assay (Shi et al. 2002). In that study, it was demonstrated that there might be different consequences of AR mutations; loss or reduction of function (48\%) were observed as well as wild-type (7\%) and gain of function (45\%). A subgroup of patients with prostate cancer presented with mutations that led to the inhibition of transcription activation function. The mutated AR Ala748Thr was rapidly degraded and expressed at a lower level in cells than in the wild-type receptor (James et al. 2002). Androgens dissociate from that mutated receptor five times faster than with the wild-type AR. Similarly, a Cys619Tyr mutation is associated with inactivation and mislocalization of the receptor (Nazareth et al. 1999).

\section{AR responsiveness through activation by non-steroidal compounds in prostate cancer and the role of the mitogen-activated protein kinase (MAPK) signalling pathway}

Among compounds that activate AR function in the absence of ligand or in a synergistic manner with low androgen doses, there is an important role of the EGF receptor-related molecule HER-2. Its overexpression resulted in enhanced growth of prostate cancer xenografts and up-regulation of PSA (Craft et al. 1999). However, HER-2 overexpression in prostate cancer is limited to a subgroup of patients and cannot account for the development of resistance in the majority of cases. Activation of the AR by HER-2 and related growth factors requires the functional pathway of MAPK (Yeh et al. 1999). Treatment of cells with the MAPK kinase inhibitor PD98059 substantially reduced PSA levels. The ability of antiandrogens to antagonize AR activation is reduced in the presence of activated MAPK (Craft et al. 1999). Prostate cancer cells engineered to express a constitutively active Ras, which up-regulates MAPK activity, became more sensitive to stimulation with lower androgen doses (Bakin et al. 2003a). In the C4-2 LNCaP subline, dominant-negative Ras restored their sensitivity to bicalutamide (Bakin et al. 2003b). This finding suggests that inhibition of Ras reverts a malignant phenotype and has a potential benefit in patients with advanced carcinoma of the prostate. MAPK activity increased in tumour specimens obtained during androgen ablation therapy (Gioeli et al. 1999). Phosphorylation of MAPK in prostate cancer cell lines correlates with their aggressiveness; PC-3 and DU-145 cells show a higher MAPK phosphorylation than LNCaP cells which have a lesser metastatic potential (Chen et al. 1999, Putz et al. 1999). High constitutive MAPK activity in DU-145 is caused by an autocrine loop involving the EGF receptor. In LNCaP and DU-145, but not in PC-3 cells, treatment with growth factors that signal through receptor tyrosine kinases and agents that elevate intracellular 
cAMP levels has a co-operative effect on MAPK activation. Results obtained with LNCaP cells suggest that elevated MAPK phosphorylation in prostate cancer occurs due to stimulation by various cytokines, one of which is TGF- $\beta$. MAPKs are involved in a mitogenic switch of TGF- $\beta$ in cancer (Park et al. 2000). TGF- $\beta$ is a well-known pleiotropic growth factor and the use of PD98059 restored a growth-inhibitory effect of TGF- $\beta$. Stimulatory effects of inhibitors of differentiation proteins on proliferation of $\mathrm{LNCaP}$ cells are associated with activation of the MAPK pathway (Ling et al. 2002). In an experimental model developed to monitor changes in IL-6 signalling in prostate cancer patients, a more malignant LNCaP subline shows activation of the MAPK pathway, in contrast to parental cells (Steiner et al. 2003). Thus, MAPK might be a common target for novel experimental therapies in human prostate cancer. In this context, MAPKs were inhibited by a flavonoid anti-oxidant silibinin, low doses of grape seed extract, the neuropeptide calcitonin, and kinin receptor antagonists (Segawa et al. 2001, Sharma et al. 2001, Tyagi et al. 2003, Barki-Harrington et al. 2003). Addition of PD98059 to treatment with docetaxel, an agent which suppresses growth by altering microtubule assembly, enhanced a growthinhibitory effect (Zelivianski et al. 2003).

Ligand-independent activation of the AR by IL-6 is also a subject of major interest (Hobisch et al. 1998, Chen et al. 2000). IL-6 up-regulation in prostate cancer occurs as a result of a concerted action of signalling pathways of nuclear factor $\kappa \mathrm{B}$, activating protein-1, and TGF- $\beta$ (Park et al. 2003, Zerbini et al. 2003). In addition, there might be an impact of androgen ablation on the elevation of IL-6 levels in prostate cancers. IL-6 binds to the IL-6 receptor which is composed of ligand-binding and signal-transducing subunits. Multiple signalling pathways, in particular those of Janus kinases/signal transducers and activators of transcription (JAK/STAT), MAPK, and phosphatidylinositol 3-kinase (PI3-K) may transmit IL-6 signal in target cells, thus being responsible for either growth stimulation or inhibition. It is not possible to clearly associate phosphorylation of STAT3, which is a characteristic feature of clinical prostate cancer, to malignant transformation (Mora et al. 2002). Phosphorylation of STAT3 in response to IL-6 was reported in experiments in which growth arrest was observed but also in connection with the cytokine's induced cell proliferation (Spiotto \& Chung 2000, Giri et al. 2001). These differences may occur because of different requirement of intermediary proteins, such as SHP-2, in IL-6 signal transduction. Functional implications of AR activation by IL- 6 were investigated in $\mathrm{LNCaP}$ cells in which there was an induction of expression of PSA mRNA and protein in association with growth retardation. It should, however, be studied as to how ligand-independent AR activation by IL- 6 regulates cellular events in other tumour models. AR activation by IL- 6 depends on the presence of coactivators p300 and SRC-1 (Debes et al. 2002, Ueda et al. 2002). It was possible to completely suppress this ligand-independent activation by treating cells with p300 small interfering (si)RNA (Debes et al. 2002). In addition to IL-6, which is produced by malignant prostate cells, other cytokines, such as oncostatin M, IL-4, and IL-8 also activate the AR (GodoyTundidor et al. 2002, Lee et al. 2003, 2004). In the presence of oncostatin $\mathrm{M}$, acquisition of agonistic activity of hydroxyflutamide was observed (GodoyTundidor et al. 2002). The cytokine regulates the growth of prostate cancers by various autocrine and paracrine loops (Mori et al. 1999, Royuela et al. 2004). IL-6 is not a single agent that causes inhibition of proliferation and stimulation of PSA in LNCaP cells; similar observations were reported after treatment with the differentiation agent butyrate (Sadar \& Gleave 2000).

In addition to classic induction of MAPK by growth factors or compounds that increase cAMP levels, these kinases are also elevated after short-term treatment with androgens. Either the AR or oestrogen receptor associate with $\mathrm{Src}$ thus stimulating the signalling pathway of Raf-1 and ERK-2 and leading to an increased proliferation of prostate cancer cells (Migliaccio et al. 2000). Surprisingly, anti-androgen hydroxyflutamide stimulated phosphorylation of MAPK in AR-negative DU-145 cells (Lee et al. 2002). This might represent another mechanism responsible for the anti-androgen withdrawal syndrome observed in prostate cancer patients. This activation led to up-regulation of cyclin D1 and enhanced cellular proliferation. AR ligand-independent activation was observed in response to $\beta$-catenin, a molecule that regulates intracellular adhesion. Neuropeptides whose expression is up-regulated in most advanced prostate tumours were shown to stimulate AR activity and proliferation (Lee et al. 2001, Dai et al. 2002).

\section{Regulation of survival of prostate cancer cells and AR activity by protein kinase Akt}

Protein kinase Akt is phosphorylated by the signalling pathway of PI3-K and overexpressed in a variety of human malignancies. AR expression and function in LNCaP cells are influenced by the PI3-K pathway 
(Manin et al. 2002). Protein kinase Akt is implicated in prostate cancer progression in an AR-dependent and AR-independent manner. Activation of the AR by HER-2 is due to Akt phosphorylation at serine 213 and 791 (Wen et al. 2000). It was reported that AR activation by Akt is characteristic for higher $\mathrm{LNCaP}$ passages; in contrast, there is an inhibitory effect in low passages (Lin et al. 2003). Akt up-regulation in prostate cancer is in part due to overexpression of the AR coactivator SRC-3 (Zhou et al. 2003). Differences in activation of the AR by non-steroidal compounds may be explained by the relative predominance of a particular signalling pathway; it was found that the pathways of JAK/STAT and MAPK enhance AR activation by IL-6, whereas the PI3-K pathway is inhibitory (Yang et al. 2003). A downstream target of Akt is the Forkhead in Human Rhabdomyosarcoma (FKHR) transcription factor, which interacts with the AR thus protecting the cells from apoptosis ( $\mathrm{Li}$ et al. 2003).

Activation of the PI3-K pathway is counteracted by the phosphoinositide phosphatase PTEN, a tumour suppressor that is commonly down-regulated in cancer. In prostate cancer, decreased PTEN expression is associated with high Gleason grade (McMenamin et al. 1999). Constitutive activation of Akt is observed in cells resistant to cytotoxic agents. LNCaP cells lost PTEN expression and showed a constitutive Akt activity (Carson et al. 1999). Consequently, PTEN reexpression in $\mathrm{LNCaP}$ cells leads to increased apoptosis. PI3-K activation is elevated in LNCaP cells after prolonged androgen ablation (Murillo et al. 2001). Androgen-independent proliferation of $\mathrm{LNCaP}$ cells occurred in parallel with loss of expression of p27 whose stability is down-regulated by PI3-K. Akt levels in the LNCaP model system correlate with tumour volume (Graff et al. 2000).

The Akt pathway is implicated in the regulation of a variety of cellular events. Constitutively active Akt is involved in androgen-initiated up-regulation of hypoxia-inducible factor-1, which is in turn stimulatory to vascular endothelial growth factor (Mabjeesh et al. 2003). Anti-apoptotic effects of insulin-like growth factor-binding protein-5, which potentiates the action of insulin-like growth factor-I, are mediated through Akt (Miyake et al. 2000). Phosphorylation of Akt is associated with $\alpha(\mathrm{V}) \beta(3)$ integrin-induced migration of prostate cancer cells on vitronectin and osteopontin (Fornaro et al. 2003). Integrins increase the levels of survivin through the Akt pathway thus preventing tumour necrosis factor- $\alpha$-induced apoptosis. Prostate cancer invasion and metastasis are regulated in part by androgens; the enzyme matrix metalloproteinase 2, whose expression is elevated in aggressive prostate cancers and is involved in degradation of extracellular matrix, is up-regulated by androgens through the PI3-K pathway (Liao et al. 2003b).

In prostate cancer, expression of the key lipogenic enzyme fatty acid synthase is up-regulated by Akt. Treatment with the PI3-K inhibitor LY294002 or transfection of PTEN cDNA led to inhibition of fatty acid synthase expression (Van de Sande et al. 2002). LNCaP cells are resistant to the apoptotic inducer tumour necrosis factor-related apoptosis-inducing ligand due to high constitutive Akt activity (Chen et al. 2001).

All these findings suggest that therapeutic intervention aimed to inhibit Akt activation is justified in prostate cancer. Celecoxib, a compound that inhibits the enzyme cyclo-oxygenase-2, is considered a potentially useful chemopreventive agent in prostate cancer. Blockade of Akt activation was observed after treatment with celecoxib and is also characteristic for an inhibitory effect of neutral endopeptidase in prostate cancer (Kulp et al. 2004). Chemoprevention or therapy of prostate cancer is in several cases associated with inhibition of Akt. Examples include black tea polyphenols and 17allylamino-17-demethoxygeldanamycin (Solit et al. 2002, Siddiqui et al. 2004).

\section{Conclusions}

Androgenic hormones are responsible for proliferative and differentiation effects in prostate. These regulations occur through activation of AR. The outcome of androgen ablation therapy in prostate cancer might be influenced by the structure of the AR, changes in its sensitivity, and interaction with partner proteins. Although various cellular adaptation mechanisms that affect AR signalling have been identified in prostate cancer, their impact on time to progression and patients' survival has not yet been clarified. In endocrine therapy-resistant prostate cancer, the signalling pathway of the AR is functional. Novel treatment options that interfere with androgen signalling have been proposed in experimental systems; however, their effectiveness in advanced prostate cancer remains to be investigated.

\section{Acknowledgements}

The authors are grateful to $\mathrm{Mr}$ Robert Schober for editorial assistance. The authors declare that there is no conflict of interest that would prejudice the impartiality of this scientific work. 


\section{References}

Adam RM, Kim J, Lin J, Orsola A, Zhuang L, Rice DC \& Freeman MR 2002 Heparin-binding epidermal growth factor-like growth factor stimulates androgenindependent prostate tumor growth and antagonizes androgen receptor function. Endocrinology 143 4599-4608.

Agus DB, Cordon-Cardo C, Fox W, Drobnjak M, Koff A, Golde DW \& Scher HI 1999 Prostate cancer cell cycle regulators: response to androgen withdrawal and development of androgen independence. Journal of the National Cancer Institiute 91 1869-1876.

Attardi BJ, Burgenson J, Hild SA \& Reel JR 2004 Steroid hormonal regulation of growth, prostate-specific antigen secretion, and transcription mediated by the mutated androgen receptor in CWR22Rv1 human prostate carcinoma cells. Molecular and Cellular Endocrinology 222 121-132.

Bakin RE, Gioeli D, Sikes RA, Bissonette EA \& Weber MJ $2003 a$ Constitutive activation of the ras/mitogen-activated protein kinase signaling pathway promotes androgen hypersensitivity in LNCaP prostate cancer cells. Cancer Research 63 1981-1989.

Bakin RE, Gioeli D, Bissonette EA \& Weber MJ $2003 b$ Attenuation of Ras signaling restores androgen sensitivity to hormone-refractory C4-2 prostate cancer cells. Cancer Research 63 1975-1980.

Barki-Harrington L, Bookout AL, Wang G, Lamb ME, Leeb-Lundberg LM \& Daaka Y 2003 Requirement for direct cross-talk between B1 and B2 kinin receptors for the proliferation of androgen-insensitive prostate cancer PC3 cells. Biochemical Journal 60 3031-3038.

Buchanan G, Yang M, Harris JM, Nahm HS, Han G, Moore N, Bentel JM, Matusik RJ, Horsfall DJ, Marshall VR, Greenberg NM \& Tilley WD 2001 Mutations at the boundary of the hinge and ligand binding domain of the androgen receptor confer increased transactivation function. Molecular Endocrinology 15 46-56.

Carson JP, Kulik G \& Weber MJ 1999 Antiapoptotic signaling in LNCaP prostate cancer cells: a survival signaling pathway independent of phosphatidylinositol 3'-kinase and Akt/protein kinase B. Cancer Research 59 1449-1453.

Chang CY, Walther PJ \& McDonnell DP 2001

Glucocorticoids manifest androgenic activity in a cell line derived from a metastatic prostate cancer. Cancer Research 61 8712-8717.

Chen CD, Welsbie DS, Tran C, Baek SH, Chen R, Vess R, Rosenfeld MG \& Sawyers CL 2004 Molecular determinants of resistance to antiandrogen therapy. Nature Medicine 10 33-39.

Chen T, Cho RW, Stork PJ \& Weber MJ 1999 Elevation of cyclic adenosine 3'5'-monophosphate potentiates activation of mitogen-activated protein kinase by growth factors in LNCaP prostate cancer cells. Cancer Research 59 213-218.
Chen T, Wang LH \& Farrar WL 2000 Interleukin 6 activates androgen receptor-mediated gene expression through a signal transducer and activator of transcription 3-dependent pathway in LNCaP prostate cancer cells. Cancer Research 60 2132-2135.

Chen X, Thakkar H, Tyan F, Gim S, Robinson H, Lee C, Pandey SK, Nwokorie C, Onwudive N \& Srivastava RK 2001 Constitutively active Akt is an important regulator of TRAIL sensitivity in prostate cancer. Oncogene 20 6073-6083.

Cinar B, Koeneman KS, Edlund M, Prins GS, Zhau HE \& Chung LW 2001 Androgen receptor mediates the reduced tumor growth, enhanced androgen responsiveness, and selected target gene transactivation in a human prostate cancer cell line. Cancer Research 61 7310-7317.

Comuzzi, B, Lambrinidis L, Rogatsch H, Godoy-Tundidor S, Knezevic N, Krhen I, Marekovic Z, Bartsch G, Klocker H, Hobisch A \& Culig Z 2003 The transciptional coactivator cAMP response element-binding proteinbinding protein is expressed in prostate cancer and enhances androgen- and anti-androgen-induced androgen receptor function. American Journal of Pathology 162 233-241.

Comuzzi B, Nemes C, Schmidt S, Jasarevic Z, Lodde M, Pycha A, Bartsch G, Offner F, Culig Z \& Hobisch A 2004 The androgen receptor co-activator CBP is up-regulated following androgen withdrawal and is highly expressed in advanced prostate cancer. Journal of Pathology 204 159-166.

Craft N, Shostak Y, Carey M \& Sawyers CL 1999 A mechanism for hormone-independent prostate cancer through modulation of androgen receptor signaling by the HER-2/neu tyrosine kinase. Nature Medicine 5 280-285.

Cronauer MV, Nessler-Menardi C, Klocker H, Maly K, Hobisch A, Bartsch G \& Culig Z 2000 Androgen Receptor Protein is down-regulated by Basic Fibroblast Growth Factor in prostate cancer cells. British Journal of Cancer 82 39-45.

Culig Z, Hobisch A, Cronauer MV, Cato ACB, Hittmair A, Radmayr C, Eberle J, Bartsch G \& Klocker H 1993 Mutant androgen receptor detected in an advanced stage of prostatic carcinoma is activated by adrenal androgens and progesterone. Molecular Endocrinology 7 1541-1550.

Culig Z, Hobisch A, Cronauer MV, Radmayr C, Hittmair A, Bartsch G \& Klocker H 1994 Androgen receptor activation in prostatic tumor cell lines by insulin-like growth factor-1, keratinocyte growth factor, and epidermal growth factor. Cancer Research 54 5474-5478.

Culig Z, Hobisch A, Herold M, Hittmair A, Thurnher M, Eder IE, Cronauer MV, Rieser C, Ramoner R, Bartsch G, Klocker H \& Konwalinka G 1998 Interleukin 1beta mediates the modulatory effects of monocytes on LNCaP human prostate cancer cells. British Journal of Cancer 78 1004-1011.

Culig Z, Hoffmann J, Erdel M, Eder I, Hobisch A, Hittmair A, Bartsch G, Utermann G, Schneider MR, Parczyk K \& 
Klocker H 1999 Switch from antagonist to agonist of the androgen receptor blocker bicalutamide is associated with prostate tumour progression in a new model system. British Journal of Cancer 81 242-251.

Dai J, Shen R, Sumitomo M, Stahl R, Navarro D, Gershengorn MC \& Nanus DM 2002 Synergistic activation of the androgen receptor by bombesin and low-dose androgen. Clinical Cancer Research $\mathbf{8}$ 2399-2405.

Debes JD, Schmidt LJ, Huang H \& Tindall DJ 2002 p300 mediates interleukin-6-dependent transactivation of the androgen receptor. Cancer Research 62 5632-5636.

Dong Y, Lee SO, Zhang H, Marshall J, Gao AC \& Ip C 2004 Prostate specific antigen expression is down-regulated by selenium through disruption of androgen receptor signaling. Cancer Research 64 19-22.

Eder IE, Culig Z, Ramoner R, Thurnher M, Putz T, Nessler-Menardi C, Tiefenthaler M, Bartsch G \& Klocker H 2000 Inhibition of LNCaP prostate cancer cells by means of androgen receptor antisense oligonucleotides. Cancer Gene Therapy 7 997-1007.

Edwards J, Krishna NS, Grigor KM \& Bartlett JM 2003 Androgen receptor gene amplification and protein expression in hormone refractory prostate cancer. British Journal of Cancer 89 552-556.

Fornaro M, Plescia J, Chheang S, Tallini G, Zhu YM, King M, Altieri DC \& Languino LR 2003 Fibronectin protects prostate cancer cells from tumor necrosis factor-alpha-induced apoptosis via the AKT/survivin pathway. Journal of Biological Chemistry $\mathbf{2 7 8}$ 50402-50411.

Fujimoto N, Yeh S, Kang HY, Inui S, Chang HC, Mizokami A \& Chang C 1999 Cloning and characterization of androgen receptor coactivator ARA55, in human prostate. Journal of Biological Chemistry 274 8316-8321.

Gao M, Ossowski L \& Ferrari AC 1999 Activation of Rb and decline in androgen receptor protein precede retinoic acidinduced apoptosis in androgen-dependent LNCaP cells and their androgen-independent derivative. Journal of Cell Physiology 179 336-346.

Gioeli D, Mandell, JW, Petroni, GR, Frierson HFJ \& Weber MJ 1999 Activation of mitogen-activated protein kinase associated with prostate cancer progression. Cancer Research 59 279-284.

Giri D, Ozen M \& Ittmann M 2001 Interleukin-6 is an autocrine growth factor in human prostate cancer. American Journal of Pathology 159 2159-2165.

Gnanapragasam VJ, Leung HY, Pulimood AS, Neal DE \& Robson CE 2001 Expression of RAC3, a steroid hormone receptor co-activator in prostate cancer. British Journal of Cancer 85 1928-1936.

Gobinet J, Poujol N \& Sultan C 2002 Molecular action of androgens. Molecular and Cellular Endocrinology 198 $15-24$.

Godoy-Tundidor S, Hobisch A, Pfeil K, Bartsch G \& Culig Z 2002 Acquisition of agonistic properties of nonsteroidal antiandrogens after treatment with oncostatin $\mathrm{M}$ in prostate cancer cells. Clinical Cancer Research $\mathbf{8}$ 2356-2361.

Graff JR, Konicek BW, McNulty AM, Wang Z, Houck K, Allen S, Paul JD, Hbaiu A, Goode RG, Sandusky GE, Vessella RL \& Neubauer BL 2000 Increased AKT activity contributes to prostate cancer progression by dramatically accelerating prostate tumor growth and diminishing p27Kipl expression. Journal of Biological Chemistry 275 24500-24505.

Gregory CW, Hamil KG, Kim D, Hall SH, Pretlow TG, Mohler JL \& French FS 1998 Androgen receptor expression in androgen-independent prostate cancer is associated with increased expression of androgenregulated genes. Cancer Research 58 5718-5724.

Gregory CW, Johnson RTJ, Mohler JL, French FS \& Wilson EM 2001a Androgen receptor stabilization in recurrent prostate cancer is associated with hypersensitivity to low androgen. Cancer Research 61 2892-2898.

Gregory CW, He B, Johnson RT, Ford OH, Mohler JL, French FS \& Wilson EM $2001 b$ A mechanism for androgen receptor-mediated prostate cancer recurrence after androgen deprivation therapy. Cancer Research 61 4315-4319.

Gregory CW, Fei X, Ponguta LA, He B, Bill HM, French FS \& Wilson EM 2004 Epidermal growth factor increases coactivation of the androgen receptor in recurrent prostate cancer. Journal of Biological Chemistry 279 7119-7130.

Haapala K, Hyytinen ER, Roiha M, Laurila M, Rantala I, Helin HJ \& Koivisto PA 2001 Androgen receptor alterations in prostate cancer relapsed during a combined androgen blockade by orchiectomy and bicalutamide. Laboratory Investigation 81 1647-1651.

Halkidou K, Gnanapragasam VJ, Mehta PB, Logan IR, Brady ME, Cook S, Leung HY, Neal DE \& Robson CN 2003 Expression of Tip60, an androgen receptor coactivator, and its role in prostate cancer development. Oncogene 22 2466-2477.

Hara T, Nakamura K, Araki H, Kusaka M \& Yamaoka M $2003 a$ Enhanced androgen receptor signaling correlates with the androgen-refractory growth in a newly established MDA PCa 2b-hr human prostate cancer cell subline. Cancer Research 63 5622-5628.

Hara T, Miyazaki J, Araki H, Yamaoka M, Kanzaki N, Kusaka M \& Miyamoto M 2003b Novel mutations of androgen receptor - A possible mechanism of bicalutamide withdrawal syndrome. Cancer Research 63 149-153.

Heinlein CA \& Chang C 2004 Androgen receptor in prostate cancer. Endocrine Reviews 25 276-308.

Heisler LE, Evangelou A, Lew AM, Trachtenberg J, Elsholtz HP \& Brown TJ 1997 Androgen-dependent cell cycle arrest and apoptotic death in prostatic cell cultures expressing a full-length human androgen receptor. Molecular and Cellular Endocrinology 126 59-73.

Henshall SM, Quinn DI, Lee CS, Head DR, Golovsky D, Brenner PC, Delprado W, Stricker PD, Grygiel JJ \& 
Sutherland RL 2001 Altered expression of androgen receptor in the malignant epithelium and adjacent stroma is associated with early relapse in prostate cancer. Cancer Research 61 423-427.

Henttu P \& Vihko P 1993 Growth factor regulation of gene expression in the human prostatic carcinoma cell line LNCaP. Cancer Research 53 1051-1058.

Hobisch A, Culig Z, Radmayr C, Bartsch G, Klocker H \& Hittmair A 1995 Distant metastases from prostatic carcinoma express androgen receptor protein. Cancer Research 55 3068-3072.

Hobisch A, Culig Z, Radmayr C, Bartsch G, Klocker H \& Hittmair A 1996 Androgen receptor status of lymph node metastases from prostate cancer. Prostate 28 129-135.

Hobisch A, Eder IE, Putz T, Horninger W, Bartsch G, Klocker H \& Culig Z 1998 Interleukin-6 regulates prostate-specific protein expression in prostate carcinoma cells by activation of the androgen receptor. Cancer Research 58 4640-4645.

Hobisch A, Ramoner R, Fuchs D, Godoy-Tundidor S, Bartsch G, Klocker H \& Culig Z 2001 Prostate cancer cells (LNCaP) generated after long-term interleukin-6 treatment express interleukin- 6 and acquire an interleukin-6-partially resistant phenotype. Clinical Cancer Research 7 2941-2948.

Hobisch A, Fiechtl M, Sandahl-Sorensen B, Godoy-Tundidor S, Artner-Dworzak E, Ramoner R, Bartsch G \& Culig Z 2004 Prostate cancer cells generated during intermittent androgen ablation acquire a growth advantage and exhibit changes in epidermal growth factor receptor expression. Prostate 59 401-408.

Holzbeierlein J, Lal P, LaTulippe E, Smith A, Satagopan J, Zhang L, Ryan C, Smith S, Scher H, Scardino P, Reuter V \& Gerald WL 2004 Gene expression analysis of human prostate carcinoma during hormonal therapy identifies androgen-responsive genes and mechanisms of therapy resistance. American Journal of Pathology 164 217-227.

Horoszewicz JS, Leong SS, Kawinski E, Karr JP, Rosenthal H, Chu TM, Mirand EA \& Murphy GP 1983 LNCaP model of human prostatic carcinoma. Cancer Research 43 1809-1818.

Hu YC, Yeh S, Yeh SD, Sampson ER, Huang J, Li P, Hsu CL, Ting HJ, Lin HK, Wang L, Kim E, Ni J \& Chang C 2004 Functional domain and motif analyses of androgen receptor coregulator ARA70 and its differential expression in prostate cancer. Journal of Biological Chemistry 279 33438-33446.

Huggins C \& Hodges CV 1941 Studies on prostatic cancer: the effects of castration, of estrogen and of androgen injection on serum phosphatases in metastatic carcinoma of the prostate. Cancer Research 1 293-297.

Hyytinen ER, Haapala K, Thompson J, Lappalainen I, Roiha M, Rantala I, Helin HJ, Janne OA, Vihinen M, Palvimo JJ \& Koivisto PA 2002 Pattern of somatic androgen receptor gene mutations in patients with hormone-refractory prostate cancer. Laboratory Investigation 82 1591-1598.
James AJ, Agoulnik IU, Harris JM, Buchanan G, Tilley WD, Marcelli M, Lamb DJ \& Weigel NL 2002 A novel androgen receptor mutant, A748T, exhibits hormone concentration-dependent defects in nuclear accumulation and activity despite normal hormone-binding affinity. Molecular Endocrinology 16 2692-2705.

Jarrard DF, Kinoshita H, Shi Y, Sandefur C, Hoff D, Meisner LF, Chang C, Herman JG, Isaacs WB \& Nassif N 1998 Methylation of the androgen receptor promoter $\mathrm{CpG}$ island is associated with loss of androgen receptor expression in prostate cancer cells. Cancer Research $\mathbf{5 8}$ 5310-5314.

Joyce R, Fenton MA, Rode P, Constantine M, Gaynes L, Kolvenbag G, DeWolf W, Balk, S \& Taplin GJ 1998 High dose bicalutamide for androgen independent prostate cancer: effect of prior hormonal therapy. Journal of Urology 159 149-153.

Kang HY, Yeh S, Fujimoto N \& Chang C 1999 Cloning and characterization of human prostate coactivator ARA54, a novel protein that associates with the androgen receptor. Journal of Biological Chemistry 274 8570-8576.

Kim D, Gregory CW, French FS, Smith GJ \& Mohler JL 2002 Androgen receptor expression and cellular proliferation during transition from androgen-dependent to recurrent growth after castration in the CWR22 prostate cancer xenograft. American Journal of Pathology $160219-226$.

Kokontis J, Takakura K, Hay N \& Liao S 1994 Increased androgen receptor activity and altered c-myc expression in prostate cancer cells after long-term androgen deprivation. Cancer Research 54 1566-1573.

Krongrad A, Wilson CM, Wilson JD, Allman DR \& McPhaul MJ 1991 Androgen increases androgen receptor protein while decreasing receptor mRNA in LNCaP cells. Molecular and Cellular Endocrinology 76 79-88.

Kulp SK, Yang YT, Hung CC, Chen KF, Lai JP, Tseng PH, Fowble JW, Ward PJ \& Chen CS 2004 3-

Phosphoinositide-dependent protein kinase-1/Akt signaling represents a major cyclooxygenase-2independent target for celecoxib in prostate cancer cells. Cancer Research 64 1444-1451.

Lee C, Sutkowski DM, Sensibar JA, Zelner D, Kim I, Amsel I, Shaw N, Prins GS \& Kozlowski JM 1995 Regulation of proliferation and production of prostatespecific antigen in androgen-sensitive prostatic cancer cells, LNCaP, by dihydrotestosterone. Endocrinology 136 796-803.

Lee LF, Guan J, Qiu Y \& Kung HJ 2001 Neuropeptideinduced androgen independence in prostate cancer cells: roles of nonreceptor tyrosine kinases Etk/Bmx, Src, and focal adhesion kinase. Molecular and Cellular Biology 21 8385-8397.

Lee LF, Louie MC, Desai SJ, Yang J, Chen HW, Evans CP \& Kung HJ 2004 Interleukin-8 confers androgenindependent growth and migration of LNCaP: differential effects of tyrosine kinases Src and FAK. Oncogene $\mathbf{2 3}$ 2197-2205. 
Lee SO, Lou W, Hou M, Onate, SA \& Gao AC 2003

Interleukin-4 enhances prostate-specific antigen expression by activation of the androgen receptor and Akt pathway. Oncogene 22 6037-6044.

Lee YF, Lin WJ, Huang J, Messing EM, Chan FL, Wilding G \& Chang $C 2002$ Activation of mitogen-activated protein kinase pathway by the antiandrogen hydroxyflutamide in androgen receptor-negative prostate cancer cells. Cancer Research 62 6039-6044.

Li P, Yu X, Ge K, Melamed J, Roeder RG \& Wang Z 2002 Heterogenous expression and functions of androgen receptor co-factors in primary prostate cancer. American Journal of Pathology 161 1467-1474.

Li P, Lee H, Guo S, Unterman TG, Jenster G \& Bai W 2003 AKT-independent protection of prostate cancer from apoptosis mediated through complex formation between the androgen receptor and FKHR. Molecular and Cellular Biology 23 104-118.

Liao G, Chen LY, Zhang A, Godavarthy A, Xia F, Ghosh JC, Li H \& Chen JD 2003a Regulation of androgen receptor activity by the nuclear receptor corepressor SMRT. Journal of Biological Chemistry 278 5052-5061.

Liao X, Thrasher JB, Pelling J, Holzbeierlein J, Sang QX \& Li B 2003 Androgen stimulates matrix metalloproteinase2 expression in human prostate cancer. Endocrinology 144 1656-1663.

Lim JT, Piazza GA, Pamukcu R, Thompson WJ \& Weinstein IB 2003 Exisulind and related compounds inhibit expression and function of the androgen receptor in human prostate cancer cells. Clinical Cancer Research 9 4972-4982.

Lin HK, Hu YC, Yang L, Altuwaijri S, Chen YT, Kang HY \& Chang C 2003 Suppression vs induction of androgen receptor functions by the phosphatidylinositol 3-kinase/ Akt pathway in prostate cancer LNCaP cells with different passage numbers. Journal of Biological Chemistry 278 50902-50907.

Ling MT, Wang X, Ouyang XS, Lee TK, Fan TY, Xu K, Tsao SW \& Wong YC 2002 Activation of MAPK signaling pathway is essential for Id-1 induced serum independent prostate cancer cell growth. Oncogene 21 8498-8505.

Linja MJ, Savinainen KJ, Saramaki OR, Tammela TL, Vessella RL \& Visakorpi T 2001 Amplification and overexpression of androgen receptor gene in hormonerefractory prostate cancer. Cancer Research 61 3550-3555.

Linja MJ, Porkka KP, Kang Z, Savinainen KJ, Janne OA, Tammela TL, Vessella RL, Palvimo JJ \& Visakorpi T 2004 Expression of androgen receptor coregulators in prostate cancer. Clinical Cancer Research 10 1032-1040.

Lu ML, Schneider MC, Zheng Y, Zhang X \& Richie JP 2001 Caveolin-1 interacts with androgen receptor. A positive modulator of androgen receptor mediated transactivation. Journal of Biological Chemistry 276 13442-13451.

Mabjeesh NJ, Willard MT, Frederickson CE, Zhong H \& Simons JW 2003 Androgens stimulate hypoxia-inducible factor activation via autocrine loop of tyrosine kinase receptor/phosphatidylinositol 3'-kinase/protein kinase B in prostate cancer cells. Clinical Cancer Research 9 2416-2425.

Manin M, Baron S, Goossens K, Beaudoin C, Jean C, Veyssiere G, Verhoeven G \& Morel L 2002 Androgen receptor expression is regulated by the phosphoinositide 3-kinase/Akt pathway in normal and tumoral epithelial cells. Biochemistry Journal 366 729-736.

McDonald S, Brive L, Agus DB, Scher HI \& Ely KR 2000 Ligand responsiveness in human prostate cancer: structural analysis of mutant androgen receptors from LNCaP and CWR22 tumors. Cancer Research 60 2317-2322.

McMenamin ME, Soung P, Perera S, Kaplan I, Loda M \& Sellers WR 1999 Loss of PTEN expression in paraffinembedded primary prostate cancer correlates with high Gleason score and advanced stage. Cancer Research 59 4291-4296.

Marcelli M, Ittmann M, Mariani S, Sutherland R, Nigam R, Murthy L, Zhao Y, DiConcini D, Puxeddu E, Esen A, Eastham J, Weigel NL \& Lamb DJ 2000 Androgen receptor mutations in prostate cancer. Cancer Research 60 944-949.

Migliaccio A, Castoria G, Di Domenico M, de Falco A, Bilancio A, Lombardi M, Barone MV, Ametrano D, Zannini MS, Abbondanza C \& Auricchio F 2000 Steroid-induced androgen receptor-oestradiol receptor beta-Src complex triggers prostate cancer cell proliferation. EMBO Journal 19 5406-5417.

Mitchell SH, Zhu W \& Young CY 1999 Resveratrol inhibits the expression and function of the androgen receptor in LNCaP prostate cancer cells. Cancer Research 59 5892-5899.

Miyake H, Nelson C, Rennie PS \& Gleave ME 2000 Overexpression of insulin-like growth factor binding protein-5 helps accelerate progression to androgen independence in the human prostate LNCaP tumor through activation of phosphatidylinositol 3-kinase pathway. Endocrinology 141 2257-2265.

Miyamoto H, Yeh S, Wilding C \& Chang C 1998 Promotion of agonist activity of antiandrogens by the androgen receptor coactivator, ARA 70, in human prostate cancer DU145 cells. PNAS 95 7379-7384.

Mizokami A, Koh E, Fujita H, Maeda Y, Egawa M, Koshida K, Honma S, Keller ET \& Namiki M 2004 The adrenal androgen androstenediol is present in prostate cancer tissue after androgen deprivation therapy and activates mutated androgen receptor. Cancer Research 64 765-771.

Mohler JL, Gregory CW, Ford OH, Kim D, Weaver CM, Petrusz P, Wilson EM \& French FS 2004 The androgen axis in recurrent prostate cancer. Clinical Cancer Research 10 440-448.

Mora LB, Buettner R, Seigne J, Diaz J, Ahmad N, Garcia R, Bowman T, Falcone R, Fairclough R, Cantor A, Muro-Cacho C, Livingston S, Karras J, Pow-Sang J \& 
Jove R 2002 Constitutive activation of Stat 3 in human prostate tumors and cell lines: direct inhibition of Stat3 signaling induces apoptosis of prostate cancer cells. Cancer Research 62 6659-6666.

Mori S, Murakami-Mori K \& Bonavida B 1999 Oncostatin $\mathrm{M}(\mathrm{OM})$ promotes the growth of DU 145 human prostate cancer cells, but not PC-3 or LNCaP, through the signaling of the OM specific receptor. AntiCancer Research 19 1011-1015.

Murillo H, Huang H, Schmidt LJ, Smith DI \& Tindall DJ 2001 Role of PI3K signaling in survival and progression of LNCaP prostate cancer cells to the androgen refractory state. Endocrinology 142 4795-4805.

Nakayama T, Watanabe M, Suzuki H, Toyota M, Sekita N, Hirokawa Y, Mizokami A, Ito H, Yatani R \& Shiraishi T 2000 Epigenetic regulation of androgen receptor gene expression in human prostate cancers. Laboratory Investigation 80 1789-1796.

Nazareth LV \& Weigel NL 1996 Activation of the human androgen receptor through a protein kinase A signaling pathway. Journal of Biological Chemistry 271 19900-19907.

Nazareth LV, Stenoien DL, Bingman WE 3rd, James AJ, Wu C, Zhang Y, Edwards DP, Mancini M, Marcelli M, Lamb DJ \& Weigel NL 1999 A C619Y mutation in the human androgen receptor causes inactivation and mislocalization of the receptor with concomitant sequestration of SRC-1. Molecular Endocrinology 13 2065-2075.

Ngan ESW, Hashimoto Y, Ma Z-Q, Tsai MJ \& Tsai SY 2002 Overexpression of $\mathrm{Cdc} 25 \mathrm{~B}$, an androgen receptor coactivator, in prostate cancer. Oncogene 22 734-739.

Nishimura K, Ting HJ, Harada Y, Tokizane T, Nonomura N, Kang HY, Chang HC, Yeh S, Miyamoto H, Shin M, Aozasa K, Okuyama A \& Chang C 2003 Modulation of androgen receptor transactivation by gelsolin: a newly identified androgen receptor coregulator. Cancer Research 63 4888-4894.

Palmberg C, Koivisto P, Kakkola L, Tammela TL, Kallioniemi OP \& Visakorpi T 2000 Androgen receptor gene amplification at primary progression predicts response to combined androgen blockade as second line therapy for advanced prostate cancer. Journal of Urology 164 1992-1995.

Park BJ, Park JI, Byun DS, Park JH \& Chi SG 2000 Mitogenic conversion of transforming growth factor betal effect by oncogenic Ha-Ras-induced activation of the mitogen-activated protein kinase signaling pathway in human prostate cancer. Cancer Research 60 3031-3038.

Park JI, Lee MG, Cho K, Park BJ, Chae KS, Byun DS, Ryu BK, Park YK \& Chi SG 2003 Transforming growth factor-betal activates interleukin-6 expression in prostate cancer cell through the synergistic collaboration of the Smad2, p38-NF-kappaB, JNK, and Ras signaling pathways. Oncogene 22 4314-4332.

Peterziel H, Culig Z, Stober J, Hobisch A, Radmayr C, Bartsch G, Klocker H \& Cato AC 1995 Mutant androgen receptors in prostatic tumors distinguish between amino-acid-sequence requirements for transactivation and ligand binding. International Journal of Cancer 63 544-550.

Petre-Draviam CE, Cook SL, Burd CJ, Marschall TW, Wetherill YB \& Knudsen KE 2003 Specificity of cyclin D1 for androgen receptor regulation. Cancer Research 63 4903-4913.

Putz T, Culig Z, Eder IE, Nessler-Menardi C, Bartsch G, Grunicke H, Überall F \& Klocker H 1999 Epidermal growth factor receptor blockade inhibits the action of EGF, insulin-like growth factor I, and a protein kinase A activator on the mitogen-activated protein kinase pathway in prostate cancer cell lines. Cancer Research 59 227-233.

Rahman MM, Miyamoto H, Takatera H, Yeh S, Altuwaijri S \& Chang C 2003 Reducing the agonist activity of antiandrogens by a dominant-negative androgen receptor coregulator ARA70 in prostate cancer cells. Journal of Biological Chemistry 278 19619-19626.

Reinikainen P, Palvimo JJ \& Janne OA 1996 Effects of mitogens on androgen receptor-mediated transactivation. Endocrinology 137 4351-4357.

Royuela M, Ricote M, Parsons MS, Garcia-Tunon I, Paniagua R \& de Miguel MP 2004 Immunohistochemical analysis of the IL- 6 family of cytokines and their receptors in benign, hyperplastic, and malignant human prostate. Journal of Pathology 202 41-49.

Sadar MD \& Gleave ME 2000 Ligand-independent activation of the androgen receptor by the differentiation agent butyrate in human prostate cancer cells. Cancer Research 60 5825-5831.

Segawa, N, Nakamura M, Nakamura Y, Mori I, Katsuoka Y \& Kakudo K 2001 Phosphorylation of mitogen-activated protein kinase is inhibited by calcitonin in DU145 prostate cancer cells. Cancer Research 61 6060-6063.

Shah RB, Mehra R, Chinnaiyan AM, Shen R, Ghosh D, Zhou M, Macvicar GR, Varambally S, Harwood J, Bismar TA, Kim R, Rubin MA \& Pienta KJ 2004 Androgen-independent prostate cancer is a heterogenous group of diseases: lessons from a rapid autopsy program. Cancer Research 64 9209-9216.

Sharma Y, Agarwal C, Singh AK \& Agarwal R 2001 Inhibitory effect of silibinin on ligand binding to erbB1 and associated mitogenic signaling, growth, and DNA synthesis in advanced human prostate carcinoma cells. Molecular Carcinogenesis 30 224-236.

Shi XB, Ma AH, Xia L, Kung HJ \& de Vere White RW 2002 Functional analysis of 44 mutant androgen receptors from human prostate cancer. Cancer Research $\mathbf{6 2}$ 1496-1502.

Siddiqui IA, Adhami VM, Afaq F, Ahmad, N \& Mukhtar H 2004 Modulation of phosphatidylinositol-3-kinase protein kinase B- and mitogen-activated protein kinase pathways by tea polyphenols in human prostate cancer cells. Journal of Cell Biochemistry 91 232-242.

Solit DB, Zheng FF, Drobnjak M, Munster PN, Higgins B, Verbel D, Heller G, Tong W, Cordon-Cardo C, Agus DB, 
Scher HI \& Rosen N 2002 17-Allylamino-17demethoxygeldanamycin induces the degradation of androgen receptor and HER-2/neu and inhibits the growth of prostate cancer xenografts. Clinical Cancer Research 8 986-993.

Spiotto MT \& Chung TD 2000 STAT3 mediates IL-6induced growth inhibition in the human prostate cancer cell line LNCaP. Prostate 42 88-98.

Steiner H, Godoy-Tundidor S, Rogatsch H, Berger AP, Fuchs D, Comuzzi B, Bartsch G, Hobisch A \& Culig Z 2003 Accelerated in vivo growth of prostate tumors that up-regulate interleukin-6 is associated with reduced retinoblastoma protein expression and activation of the mitogen-activated protein kinase pathway. American Journal of Pathology 162 655-663.

Tan J, Sharief Y, Hamil KG, Gregory CW, Zang DY, Sar M, Gumerlock PH, deVereWhite RW, Pretlow TG, Harris SE, Wilson EM, Mohler JL \& French FS 1997 Dehydroepiandrosterone activates mutant androgen receptors expressed in the androgen-dependent human prostate cancer xenograft CWR22 and LNCaP cells. Molecular Endocrinology 11 450-459.

Taneja SS, Ha S, Swenson NK, Torra IP, Rome S, Walden PD, Huang HY, Shapiro E, Garabedian MJ \& Logan SK 2004 ART-27, an androgen receptor coactivator regulated in prostate development and cancer. Journal of Biological Chemistry 279 13944-13952.

Taplin ME, Bubley GJ, Ko YJ, Small EJ, Upton M, Rajeshkumar B \& Balk SP 1999 Selection for androgen receptor mutations in prostate cancers treated with androgen antagonist. Cancer Research 59 2511-2515.

Taplin ME, Rajeshkumar B, Halabi S, Werner CP, Woda BA, Picus J, Stadler W, Hayes DF, Kantoff PW, Vogelzang NJ \& Small EJ 2003 Androgen receptor mutations in androgen-independent prostate cancer: Cancer and Leukemia Group B Study 9663. Journal of Clinical Oncology 21 2673-2678.

Tepper CG, Boucher DL, Ryan, PE, Ma AH, Xia L, Lee LF, Pretlow TG \& Kung HJ 2002 Characterization of a novel androgen receptor mutation in a relapsed CWR22 prostate cancer xenograft and cell line. Cancer Research 62 6606-6614.

Thalmann GN, Anezinis PE, Chang SM, Zhau HE, Kim EE, Hopwood VL, Pathak S, von Eschenbach AC \& Chung LW 1994 Androgen-independent cancer progression and bone metastasis in the $\mathrm{LNCaP}$ model of human prostate cancer. Cancer Research 54 2577-2581.

Thompson J, Hyytinen ER, Haapala K, Helin HJ, Janne OA, Palvimo JJ \& Koivisto PA 2003 Androgen receptor mutations in high-grade prostate cancer before hormonal therapy. Laboratory Investigation 83 1709-1713.

Tyagi A, Agarwal R \& Agarwal C 2003 Grape seed extract inhibits EGF-induced and constitutively active mitogenic signaling but activates JNK in human prostate carcinoma DU145 cells: possible role in antiproliferation and apoptosis. Oncogene 22 1302-1316.
Ueda T, Mawji NR, Bruchovsky N \& Sadar MD 2002 Ligand-independent activation of the androgen receptor by interleukin- 6 and the role of steroid receptor coactivator-1 in prostate cancer cells. Journal of Biological Chemistry 277 38087-38094.

Van der Kwast TH, Schalken J, Ruizeveld de Winter JA, van Vroonhoven CCJ, Mulder E, Boersma W \& Trapman J 1991 Androgen receptors in endocrine-therapy-resistant human prostate cancer. International Journal of Cancer $\mathbf{4 8}$ 189-193.

Van de Sande T, De Schrijver, E, Heyns W, Verhoeven G \& Swinnen JV 2002 Role of the phosphatidylinositol 3kinase/PTEN kinase pathway in the overexpression of fatty acid synthase in LNCaP prostate cancer cells. Cancer Research 62 642-646.

Veldscholte J, Ris-Stalpers C, Kuiper GGJM, Jenster G, Berrevoets C, Claassen E, van Rooij HCJ, Trapman J \& Brinkmann AO 1990 A mutation in the ligand binding domain of the androgen receptor of human LNCaP cells affects steroid binding characteristics and response to anti-androgens. Biochemical and Biophysical Research Communications 17 534-540.

Veldscholte J, Berrevoets CA, Zegers ND, van der Kwast TH, Grootgoed JA \& Mulder E 1992 Hormone-induced dissociation of the androgen receptor-heat-shock protein complex: use of a new monoclonal antibody to distinguish transformed from nontransformed receptors.

Biochemistry 31 7422-7430.

Visakorpi T, Hyytinen E, Koivisto P, Tanner M, Keinänen R, Palmberg C, Palotie A, Tammela T, Isola J \& Kallioniemi OP 1995 In vivo amplification of the androgen receptor gene and progression of human prostate cancer. Nature Genetics 9 401-406.

Wang LG, Ossowski L \& Ferrari AC 2001 Overexpressed androgen receptor linked to p21WAF1 silencing may be responsible for androgen independence and resistance to apoptosis of a prostate cancer cell line. Cancer Research $617544-7551$.

Wen Y, Hu MC, Makino K, Spohn B, Bartholomeusz G, Yan DH \& Hung MC 2000 HER-2/neu promotes androgen-independent survival and growth of prostate cancer cells through the Akt pathway. Cancer Research 60 6841-6845.

Wu HC, Hsieh JT, Gleave ME, Brown NM, Pathak S \& Chung LW 1994 Derivation of androgen-independent human LNCaP prostatic cancer cell sublines: role of bone stromal cells. International Journal of Cancer 57 406-412.

Xing N, Chen Y, Mitchell SH \& Young CY 2001 Quercetin inhibits the expression and function of the androgen receptor in LNCaP prostate cancer cells. Carcinogenesis 22 409-414.

Yamamoto A, Hashimoto Y, Kohri K, Ogata E, Kato S, Ikeda K \& Nakanishi M 2000 Cyclin E as a coactivator of the androgen receptor. Journal of Cell Biology $\mathbf{1 5 0}$ 873-880.

Yang L, Wang L, Lin HK, Kan PY, Xie S, Tsai MY, Wang PH, Chen YT \& Chang C 2003 Interleukin-6 differentially 
regulates androgen receptor transactivation via $\mathrm{PI} 3 \mathrm{~K}$ Akt, STAT3, and MAPK, three distinct signal pathways in prostate cancer cells. Biochemical and Biophysical Research Communications 305 462-469.

Yeh S, Miyamoto H, Nishimura K, Kang H, Ludlow J, Hsiao P, Wang C, Su C \& Chang C 1998 Retinoblastoma, a tumor suppressor is a coactivator for the androgen receptor in human prostate cancer DU-145 cells. Biochemical and Biophysical Research Communication 248 361-367.

Yeh S, Lin HK, Kang HY, Thin TH, Lin MF \& Chang C 1999 From HER2/Neu signal cascade to androgen receptor and its coactivators: a novel pathway by induction of androgen target genes through MAP kinase in prostate cancer cells. PNAS 96 5458-5463.

Yeh S, Hu YC, Rahman M, Lin HK, Hsu CL, Ting HJ, Kang HY \& Chang C 2000 Increase of androgeninduced cell death and androgen receptor transactivation by BRCA1 in prostate cancer cells. PNAS 97 11256-11261.

Zegarra-Moro OL, Schmidt LJ, Huang H \& Tindall DJ 2002 Disruption of androgen receptor function inhibits proliferation of androgen-refractory prostate cancer cells. Cancer Research 62 1008-1013.

Zelivianski S, Spellman, M, Kellerman M, Kakitelashvilli V, Zhou XW, Lugo E, Lee MS, Taylor R, Davis TL, Hauke R \& Lin MF 2003 ERK inhibitor PD98059 enhances docetaxel-induced apoptosis of androgen-independent human prostate cancer cells. International Journal of Cancer 107 478-485.
Zerbini LF, Wang Y, Cho JY \& Libermann TA 2003 Constitutive activation of nuclear factor kappaB p50/p65 and Fra-1 and JunD is essential for deregulated interleukin 6 expression in prostate cancer. Cancer Research 63 2206-2215.

Zhang Y, Ni J, Messing EM, Chang E, Yang CR \& Yeh S 2002 Vitamin E succinate inhibits the function of androgen receptor and the expression of prostatespecific antigen in prostate cancer cells. PNAS 99 7408-7413.

Zhao XY, Boyle B, Krishman AV, Navone NM, Peehl DM \& Feldman D 1999a Two mutations identified in the androgen receptor of the new human prostate cancer cell line MDA PCa 2a. Journal of Urology 162 2192-2199.

Zhao XY, Ly LH, Peehl DM \& Feldman D $1999 b$ Induction of androgen receptor by 1alpha, 25-dihydroxivitamin D3 and 9-cis retinoic acid in LNCaP human prostate cancer cells. Endocrinology 140 1205-1212.

Zhao XY, Malloy PJ, Krishman AV, Swami S, Navone NM, Peehl DM \& Feldman D 2000 Glucocorticoids can promote androgen-independent growth of prostate cancer cells through a mutated androgen receptor. Nature Medicine 6 703-706.

Zhou G, Hashimoto Y, Kwak I, Tsai SY \& Tsai MJ 2003 Role of the steroid receptor coactivator SRC-3 in cell growth. Molecular and Cellular Biology 23 7742-7755.

Zhu W, Smith A \& Young CY 1999 A nonsteroidal antiinflammatory drug, flufenamic acid, inhibits the expression of androgen receptor in LNCaP cells. Endocrinology 140 5451-5454. 